\title{
Governing Capacity and Institutional Change in China in the Reform Era
}

\author{
KJELD ERIK BRØDSGAARD
}

\begin{abstract}
The Chinese reform process of 1978-2008 has primarily taken place within the economic sphere, involving fundamental changes of the centrally planned economic system. As a result, a hybrid economic system has evolved based on a combination of resource mobilization and allocation by market forces and Party and state domination of the commanding heights of the economy. In the political sphere, reform has been much more limited. During the 1980s there were several periods of substantial political reform, but since the early 1990s reform has largely been synonymous with improvement of the governance system in terms of capacity of institutions and competencies of officials. Thus administrative reform and institutional changes have been placed high on the agenda, emphasizing administrative restructuring and downsizing of government organs as well as Party reform. Party reform and leadership renewal have created an institutionalized political order characterized by incremental change within the framework of authoritarian resilience. Currently, major reform discussion in China primarily takes place within the Party organization and focuses on perfecting the existing political system rather than on introducing Western models and experiences.
\end{abstract}

Keywords: China, political reform, public management, civil servants, Party renewal, institutionalization

\section{Introduction}

Since 1978 China has undergone substantial economic reform. As a result the country can no longer be categorized as a centrally planned economic system. What we see is rather a hybrid system with most resources being mobilized and allocated through market forces, but with the commanding heights of the economy heavily influenced by the Party-state. Economic reform has also been associated with an 'opening' to the outside world in terms of trade and investment and today China is deeply integrated into the global economic order, as evidenced by the recent economic slowdown in China following the onset of the current global financial crisis. In the political sphere, reform has been much more 
limited. There were signs of substantial reform in the 1980s. Thus the Gengshen reforms put forward by Liao Gailong in 1980 aimed to introduce a less centralized political system and in 1987-88 Zhao Ziyang and his supporters were engaged in working out a set of reform proposals under the theme of 'separating party and government'. However, during the 1990s, following the Tiananmen debacle, substantial political reform was taken off the agenda. Instead, the focus changed towards administrative reform. The aim has not been to fundamentally change the political system in a more pluralistic or democratic direction, but rather to improve the governance system. This paper will primarily address two important aspects of administrative reform: (1) administrative restructuring and downsizing of government organs and (2) Party reform. It will be argued that whereas administrative restructuring has largely failed, Party reform has created an institutionalized political order that seems to be based on widespread legitimacy among the Chinese population. In fact, currently the reform discussion primarily takes place within the Party organization and focuses on improving and perfecting the existing political system, rather than on abolishing it in favour of a democratic order of the Western type.

\section{Institutional Reform}

Institutional reform in the post-Mao era has been based on the assumption that the Chinese bureaucracy is too big and cumbersome. The widely held belief was that there were too many administrative organs staffed by an excess number of personnel. At intervals of about five years, that is, in 1982, 1988, 1993, 1998, 2003 and 2008, there were attempts to streamline and downsize the bureaucracy to create a leaner government structure. Noteworthy is the 1998 round of administrative reform, when former Prime Minister Zhu Rongji announced that the Chinese bureaucracy would be cut by 50 percent (Brødsgaard 2002). As there were around ten million cadres employed in state and Party administrative organs at central and local levels, this would mean that around five million people were thought to be redundant.

Most of these rounds of institutional reform were based on the assumption that downsizing the bureaucracy would increase efficiency. They were not based on a thorough assessment of which government functions and organs were really needed in a qualitative sense and whether the Chinese state, compared to other countries, was really that overblown. The 1998 round of administrative reform introduced 
a change of perspective in the sense that it introduced the so-called san ding as the basis for change of the bureaucratic system (Brødsgaard 2002: 361-62). This concept has three dimensions. The first is to determine the functions needed in the public sector (ding zhineng). The second dimension of the concept is to fix the number of administrative organs (ding jiguan) on the basis of the defined core functions. The third aspect is about determining the number of personnel (ding renyuan). This would be done on the basis of the functions and administrative organs deemed necessary. Administrative organs would be allocated personnel according to the functions and tasks they were supposed to take care of.

The 1998 administrative reform reduced the number of ministerial-level working departments of the State Council from 41 to 29 and downsized central-level staff of the State Council from 32,000 to 16,000 (Brødsgaard 2002). A number of the old branch ministries in the machinery and heavy-industrial sector, which had existed since the Soviet-style planning system was introduced in the early 1950s, were organized into bureaus under the State Economic and Trade Commission (SETC), thereby losing their ministerial-level status. Other ministries were merged such as the Ministry of Electrical Industry, the Ministry of Post and Communications, and the Ministry of Radio, Film and Television. They had their functions and personnel transferred to a new Ministry of Information Industry.

In 2003 a new but less dramatic reform of the administrative system was carried out (Holbig 2003; Voita 2008). The reform involved the establishment of a new State-Owned Asset Supervisory and Administration Commission, embracing divisions of the State Economic and Trade Commission and of the Ministry of Finance responsible for supervising and managing state-owned assets as well as the Central Enterprise Work Commission. Moreover, the State Development Planning Commission was restructured into a new body: the National Development and Reform Commission (NDRC). The responsibilities included macroeconomic adjustment and control. A Ministry of Commerce was re-established consisting of a merger of the main part of the State Economic and Trade Commission and the Ministry of Foreign Trade and Co-operation. Finally, a new Food and Drug Administration was established and existing financial regulatory bodies were reorganized into the People's Bank of China, China Banking Regulatory Commission and China Insurance Regulatory Commission. As a result there were 28 ministries and commissions as well as 18 organs directly under the State Council (guowuyuan zhishu jigou) and six working organs of the State 
Council (guowuyuan banshi jigou), including the General Office of the State Council (China Directory 2004; Liu 2003). This was not an excessive number of central administrative organs, compared to the past.

However, the Chinese government continued to be concerned about the administrative structure at the central level. There were voices arguing for further streamlining of administrative organs as well as personnel. In his report to the Seventeenth Party Congress in October 2007, $\mathrm{Hu}$ Jintao claimed that administrative reform was an important part of efforts to deepen China's overall reform and that the government 'must lose no time' in working out a master plan for it. This involved stepping up efforts to streamline government organs and exploring ways to establish 'greater departments' with integrated functions (Hu 2007).

By 'greater departments' Hu meant a system of larger ministries or superministries (da bumen tizhi) within priority areas. The goal was to create a number of strong ministries that would bring together related functional areas. The long-term perspective was to establish 'a relatively perfect socialist administrative management system with Chinese characteristics' by the year 2020 (Renmin ribao 2008a).

The plan was worked out during early 2008. A draft plan as well as a document explaining the goals and principles of the plan were discussed at the plenary meeting of the Central Committee in February 2008 (Renmin ribao 2008b). Following approval by the Party leaders, the plan was presented to the National People's Congress at its spring session in March and formally adopted on March 15 (Hua Jianmin 2008; Xinhua she 2008).

According to the plan, five new superministries would be established (Liu 2008; Hua Jianmin 2008; Renmin ribao 2008c). They were the Ministry of Industry and Information, the Ministry of Human Resources and Social Security, the Ministry of Transport, the Ministry of Housing and Urban-Rural Construction and the Ministry of Environmental Protection. Other changes included bringing the State Food and Drug Administration under the governance of the Ministry of Health and reorganizing parts of the National Development and Reform Commission.

The Ministry of Industry and Information was assigned the functions of managing the industrial branches of the NDRC that the Commission had taken over from SETC in 2003 as well as the functions of the Ministry of Information Industry that had been established in 1998. Except for management of nuclear energy, the functions of the Commission of Science, Technology and Industry for National Defence were also transferred to the new ministry as were the State Council Information 
Office and the State Bureau of Tobacco Sales. This bureau had formerly belonged to NDRC.

The Ministry of Human Resources and Social Security was created as a merger of the Ministry of Personnel and the Ministry of Labour and Social Security. In the administrative reform of 1988 the Ministry of Labour and Personnel had been split into two ministries, i.e., the Ministry of Labour and the Ministry of Personnel. In 1998 the social security portfolio was added to the Ministry of Labour to reflect the increased importance attached to social security work. The new Ministry of Human Resources and Social Security established a new bureau for managing state civil servants. In the past this had been a function of the Ministry of Personnel.

The Ministry of Communications and the State Administration of Civil Aviation together with the tasks and functions of the urban public transport department of the Ministry of Construction were merged to form the new Ministry of Transportation. The intention was to integrate highway, waterway and air transportation. However, the powerful Ministry of Railways is to keep its independent status in light of 'the consideration of the special needs' in managing the railways.

The Ministry of Construction was renamed the Ministry of Housing and Urban-Rural Construction. Its functions in regulating public transportation in the cities were relocated to the newly formed Ministry of Transportation. Finally, the State Environment Protection Agency (SEPA) was upgraded to the Ministry of Environmental Protection.

Other adjustments included upgrading the State Energy Office to the State Energy Bureau, which remained under the jurisdiction of the National Development and Reform Commission. The new bureau was supposed to integrate the functions of NDRC in relation to energy management with the functions of the national leading group on energy. The State and Drug Administration, which had previously been located directly under the State Council, was merged into the Ministry of Health.

The reorganization affected 15 government organs and reduced the number of ministries and commissions from 28 to $27-$ three of these were commissions (Renmin ribao 2008c; Guowuyuan jigou gaige qingkuang yi lanbiao 2008). This was a less substantial downsizing and reorganization than originally anticipated and voices were raised as to the effectiveness and sincerity of the structural reform process. Two examples illustrate this. First, it had not been possible to merge the Ministry of Railways with the new Ministry of Transportation. Powerful 
interests were against the merger since it would have downgraded the importance of the railways in China's transportation system. Second, the idea of creating a Ministry of Energy was abandoned. Here again administrative reform encountered heavy resistance from entrenched interests. The big state-owned enterprises (SOEs) within the energy sector were against the establishment of a ministry that would interfere with their activities.

Many of the large SOEs carry ministerial rank and have developed into independent fiefdoms and no longer see themselves as part of a command chain extending from central ministries downward. In this sense, some of the ministries within heavy industry, where most of the large SOEs are located, have lost their former power. Such a development trend, in combination with reduction of ministries and agencies, has weakened the government's ruling capacity. In short, administrative reform in the form of quantitative downsizing of government organs and personnel has largely failed. This is not only because of systemic reasons (bureaucrats unwilling to give up their positions), but also because the transition from a centrally planned to a market-based society creates new tasks and functions the state has to take care of such as health care, improved education, etc., and this again calls for more, rather than less, personnel. Finally, as a result of enterprise reform and restructuring some of the SOEs, especially within energy, have grown in importance and have become so big and well connected that they are challenging the authority of government. Their CEOs are not appointed by government ministries, but by the Organizational Department of the Central Committee, reflecting the weight they carry in the Chinese administrative system (Author's Notes 2005).

\section{Party Reform and Cadre Management}

During the early phase of the democracy movement in 1978-79 it appeared as if Deng Xiaoping was supporting the demands of the young activists (Brødsgaard 1981). However, when leaders of the movement began to criticize the leading role of the Party and even Deng Xiaoping himself, a break was unavoidable. Deng demanded that debate bringing the socialist system into question was to be stopped and that in the future political discussions were to uphold the 'Four Principles'. When Wei Jingsheng and other activists responded with attacks on Deng Xiaoping, they were arrested and the democracy movement was suppressed. This did not mean that discussion of political reform was banned, but 
it meant that it would take place within the framework of the system and that the goal would be to perfect and improve the existing political system - not to abolish it. It would be part of attempts to reform state, Party and leadership systems from within.

Party reform originated in the early 1980s and was originally part of Deng Xiaoping's attempt to reform the leadership systems. Already in 1980 Deng repeatedly stressed that Party and state were too intertwined and that reform was needed so that the Party would not take on everything. He defined five obstacles to political reform: 1) bureaucracy, 2) over-concentration of power, 3) patriarchal methods, 4) lifelong tenure of leading posts and 5) various kinds of privileges (Brødsgaard 1987). In addition, on several occasions Deng stressed the need to create a younger, better educated and more professionally competent cadre corps. At a seminar held by the national Party school system in October 1980, Liao Gailong, a member of the Policy Research Office of the Central Committee, further elaborated on these reform proposals. He suggested that the Central Committee no longer should enjoy absolute power and that there should be established three central committees that would 'mutually supervise and impose constraints on each other' (Brødsgaard 1987: 43). These three bodies should be called the Central Executive Committee (the former Central Committee), the Central Discipline Inspection Committee and the Central Supervisory Committee. The members of the last committee would be 'revolutionaries' of the older generation who had rich experience and were able to work but were rather weak physically. He also proposed to divide the National People's Congress into two houses that would represent different territorial and functional interests. There should also be an independent judiciary that would have the authority to pass a verdict without sending it to a party committee for examination and approval. Liao Gailong's Gengshen reform amounted to a system characterized by 'checks and balances' between various political institutions and organs rather than by the exclusive dominance of a strong and centralized party. In 1982 a Central Advisory Committee of old revolutionaries was created along the lines of Liao Gailong's suggestion. However, the intention was to create a forum for retired cadres rather than an attempt to establish a body that would limit the power of the Central Committee. That this Central Advisory Committee eventually became quite powerful is another matter.

In 1986, after five years of concentration on economic issues, political reform was again placed at the top of the political agenda. Again the initiative was taken by Deng. It was proposed to reduce the power 
of local governments and local Party committees. Another proposal concerned reducing the power of the Enterprise Party Committee to strengthen the management role of enterprise directors.

However, student demonstrations in December 1986 weakened the reform-oriented $\mathrm{Hu}$ Yaobang, who in January 1987 was forced to step down as General Secretary by the intervention of leading members of the Central Advisory Committee. The new party leader, Zhao Ziyang, was also in favour of political reform and his report to the thirteenth Party Congress clearly expressed his conviction that this was the only way forward for China. In the report he proposed that the Party no longer should overlap or duplicate existing government organizations. Therefore, the system of Party groups (dangzu) within government units should be abolished (Zhao 1987). A second important initiative was a proposal to reform the personnel system for different categories of cadres. According to Zhao Ziyang, in the future cadres should be divided into two categories, a political-administrative category and a professional work category. Only the former category should be managed by the Party.

Following Zhao's report, several concrete proposals on how to separate party and government and to limit central control were formulated. One of the more interesting was put forward in 1988 when Hainan Island was granted status as a special economic zone and given provincial status (Brødsgaard 2009). The reform initiatives in Hainan were subsumed under the slogan 'small government, big society'. Work was also initiated to establish a civil service system according to which cadre appointment would take place according to fixed norms and rules.

The 1989 Tiananmen debacle made it impossible to pursue these plans. To the leadership the crisis demonstrated the necessity to strengthen the governance system, including party organization and cadre management. A push for pluralization and the stimulation of new social associations and movements were no longer on the agenda. The reform discussion was brought into the Party and became very much synonomous with establishing more efficient systems of governance. ${ }^{1}$ The Chinese leadership carefully studied the breakdown of the Soviet Union and concluded that the key to preventing something similar from happening in China was to create a more efficient and clean Party and government structure (Shambaugh 2008). 


\section{Cadre Management and Civil Servants}

Cadre management is crucial in an authoritarian system of the Chinese type (Bo 2004; Brødsgaard 2004; Burns 2004). Most Chinese only experience the power system when they deal with the representatives of the governing elite, namely the cadres. How this encounter plays out to a high degree determines the attitude of ordinary Chinese towards the regime as such. To gain or regain legitimacy, the post-Tiananmen regime focused on a number of measures to upgrade public management in China.

First, measures were introduced to create a younger cadre corps (Brødsgaard 2004). Lifelong tenure was abolished and retirement criteria were introduced for state cadres. Ministerial-level cadres were expected to retire at 65 for men and at 60 for women. The Central Organization Department issued a 'cadre development programme' that stipulated age criteria for leaders and leadership at various levels from the central level to the division level.

Second, there was a new focus on the educational background of cadres. This was especially stressed during the 1990s and in 1995 regulations were published that stipulated that an educational level higher than vocational school generally was required for leading cadres, and that leading cadres at the minister or provincial-leader level should have a college education or equivalent. Gradually, competitive examinations for government jobs were also introduced, further stressing the meritocratic nature of the new cadre corps.

Third, evaluation of performance was introduced. Evaluation became part of the procedures for appointment and promotion. Leading members of party committees and government departments were also to be evaluated in the middle of their term. Increasingly, promotion became dependent on the evaluation of work performance.

Fourth, the nomenklatura system was consolidated. The CEOs of the largest companies were again brought under Party control and were managed and appointed by the Organizational Department of the Central Committee. From 2003, SASAC controlled the appointment of the CEOs of the rest of the 'national champions'.

Fifth, a civil service system was introduced in 1993. The concept of a modern civil service was conceived in the mid-1980s and became part of the reform-oriented policies pursued by Zhao Ziyang. However, due to the political fallout from the Tiananmen debacle it only became possible to implement a revised version of the original plans in 1993, following 
Deng's Southern Trip (nanxun) and the Fourteenth Party Congress. The Provisional Regulations on Civil Servants contained stipulations concerning employment, appraisals, rewards, discipline, appointment and removal, training, rotation, retirement, appeals and complaints, management and supervision, etc. (Guojia guowuyuan zanxin tiaoli 1993). The civil service system was further elaborated and developed during the 1990s. It regulated the about ten million civil servants in China in terms of rank, salary, promotion, rotation, dismissal, etc. In early 2005 the provisional regulations were revised and published as 'The Civil Service Law of the People's Republic of China'. It took effect from 1 January 2006 and has added a few adjustments such as a new chapter on employment contracts and staffing quotas. The law also indicates a greater focus on qualifications in terms of examinations as well as making the recruitment process more transparent. In general the new law has more focus on the role of the Party than the previous draft regulations (Zhonghua Renmin Gongheguo gongwuyuan fa 2005).

Recently there have also been renewed attempts to reform the large and diverse sector of public service units (shiye danwei). This important part of the public sector employs almost 27 million workers and staff and includes hospitals, schools, kindergartens, universities, publishing houses and other institutions in healthcare, sports, social welfare, culture and research. The aim is to transform many public service units into commercialized operations that rely on their own ability to generate economic resources. As a consequence, their staff will be clearly separated from the civil service and remunerated according to different pay scales. The Chinese government believes that by establishing a clear distinction between public service units and the civil service system (core government) it will be possible to create a more efficient public administration (Central Government Research Team 2008).

\section{Younger and Better Educated Cadres}

Did the leadership succeed in achieving these goals of creating a younger and better educated cadre cohort? Statistics show that from 1980 to 1998 the number of younger cadres has increased significantly (Brødsgaard 2004). In 1979 only 29 percent of the cadres were below 35 years of age. This percentage rose to 49 percent in 1998. The share of cadres between 36 and 54 years of age has fallen from 65 percent in 1979 to 45 percent in 1998. This leaves a share of only 6 percent for cadres at 55 years of age and above. 
The educational level of cadres improved dramatically during the reform period. While the share of cadres with junior middle school education and below was almost 50 percent in 1979, it went down to 7.8 percent in 1998 . Now almost 47 percent of the cadre corps has a university degree compared to only 18 percent in 1979 and 7 percent in 1950. Among leading cadres, the share of people with a university degree has gone up from 16 percent in 1980 to 81 percent ín 1998. Now more than 95 percent of the Central Committee holds a college degree.

TABLE 1: Educational Background of Cadres in China, 1979-98

\begin{tabular}{|c|c|c|c|c|}
\hline Year & $\begin{array}{c}\text { Number } \\
\text { (mill.) }\end{array}$ & $\begin{array}{c}\text { University } \\
\text { degree } \\
\text { Number (\%) }\end{array}$ & $\begin{array}{c}\text { Senior High } \\
\text { Number (\%) }\end{array}$ & $\begin{array}{c}\text { Junior High and below } \\
\text { Number (\%) }\end{array}$ \\
\hline 1979 & 18.14 & $3.25(17.9)$ & $6.05(33.4)$ & $8.83(48.7)$ \\
\hline 1985 & 26.53 & $5.80(21.9)$ & $12.12(45.6)$ & $8.63(32.5)$ \\
\hline 1988 & 30.45 & $8.61(28.3)$ & $14.43(47.4)$ & $7.41(24.3)$ \\
\hline 1991 & 34.97 & $11.62(33.2)$ & $16.67(47.7)$ & $6.69(19.1)$ \\
\hline 1992 & 35.89 & $12.52(34.9)$ & $17.1847 .9)$ & $6.19(17.2)$ \\
\hline 1993 & 36.99 & $13.40(36.2)$ & $17.95(48.5)$ & $5.65(15.3)$ \\
\hline 1994 & 37.96 & $14.27(37.6)$ & $18.48(48.7)$ & $5.21(13.7)$ \\
\hline 1995 & 38.32 & $15.20(39.7)$ & $18.54(48.4)$ & $4.58(11.9)$ \\
\hline 1996 & 39.32 & $16.49(41.9)$ & $18.71(46.6)$ & $4.12(10.5)$ \\
\hline 1997 & 40.19 & $17.73(44.1)$ & $18.42(46.6)$ & $3.71(9.3)$ \\
\hline 1998 & 40.49 & $18.75(46.5)$ & $18.43(45.5)$ & $3.22(8.0)$ \\
\hline
\end{tabular}

Source: Zhonggong zhongyang zuzhibu 2000: 1350-52.

TABLE 2: Educational Background of Leading Cadres

\begin{tabular}{|c|c|cc|cc|}
\hline \multirow{2}{*}{ Year } & \multirow{2}{*}{ Number } & \multicolumn{2}{|c|}{ University degree } & \multicolumn{2}{|c|}{ Junior High and below } \\
Number & $\mathbf{( \% )}$ & Number & \% \\
\hline 1981 & 183,927 & 30,127 & $(16.4)$ & 106,274 & $(57.8)$ \\
\hline 1985 & 259,596 & 101,361 & $(39.1)$ & 79,365 & $(30.6)$ \\
\hline 1988 & 317,123 & 146,154 & $(46.1)$ & 74,544 & $(23.5)$ \\
\hline 1991 & 361,512 & 200,852 & $(55.6)$ & 61,236 & $(16.9)$ \\
\hline 1992 & 376,773 & 222,029 & $(58.9)$ & 55,889 & $(14.8)$ \\
\hline 1993 & 398,189 & 249,354 & $(62.6)$ & 49,039 & $(12.3)$ \\
\hline 1994 & 404,119 & 270,996 & $(66.7)$ & 39,422 & $(9.7)$ \\
\hline 1995 & 445,286 & 315,165 & $(70.8)$ & 34,466 & $(7.9)$ \\
\hline 1996 & 468,274 & 346,994 & $(74.1)$ & 30,532 & $(6.5)$ \\
\hline 1997 & 492,328 & 381,561 & $(77.5)$ & 25,705 & $(5.2)$ \\
\hline 1998 & 508,025 & 409,090 & $(80.5)$ & 21,202 & $(4.2)$ \\
\hline
\end{tabular}

Source: Zhonggong zhongyang zuzhibu 2000: 1344-47. 


\section{Institutionalization}

These changes seem to indicate an institutionalization of the political process in China (Bo 2004; Huang 2008; Miller 2008). This impression was considerably strengthened in 2002-03 when China underwent a peaceful, orderly, deliberate and rule-bound transition from the third to fourth generation of leaders. Again, in November 2007, two leading members of the fifth generation were brought into the politbureau standing committee without the heavy leadership struggle of the past. Thus it appears that, when selecting and promoting new leaders, formal rules and compliant procedures have prevailed over factional policies based on informal personal relations. This trend of institutionalization combines with the current strengthening of inner party democracy. A tenure system for party delegates, a bigger say for party committees vis-à-vis the standing committees, as well as new voting procedures are now being suggested.

In this context it is a setback that the Chinese leadership has given up on its attempts to separate Party and government work. The slogan of 'separating party from government' figured prominently during Jiang Zemin's era but is no longer present in the public discourse. There are numerous references to the need to separate government and enterprises (zhengqi fenkai), government and affairs (zhengshi fenkai) and government and funds (zhengzi fenkai), but there is silence concerning the slogan of separating government from Party work and affairs (zhengdang fenkai).

Instead there is much talk of merging Party and government departments whose functions are similar and creating a system of overlapping of post and leading members of the Party and government (dangzheng lingdao chengyuan jiaocha zhiwu). Thus, in many counties the party secretary has taken over the position as head of the county in addition to chairman of the local People's Congress. The vice-party secretary is often put in charge of the functional departments of the local government.

Allegedly, the aim is to save on the budget by having fewer administrative heads in charge. In addition, this measure is viewed as a way of improving and streamlining administrative performance by concentrating local executive and legal powers in fewer hands. However, this thinking is a reflection of a quantitative approach and therefore runs counter to more qualitative attempts to create a more efficient government. In short, it goes against the call of the Beijing Consensus for transparency and a system of checks and balances. 


\section{Concluding Remarks: Headed Towards Democracy?}

Developments in China over the last 30 years challenge the so-called transition paradigm. This paradigm posits that once a country moves away from dictatorial rule there is a linear process towards democracy and pluralism (Brødsgaard and Zheng 2004). The transition paradigm also assumes that authoritarian regimes are fragile due to weak legitimacy, too much focus on political oppression, over-centralization of the political decision-making process and the dominance of personal power (patrimonialism) over institutional norms.

On the surface, China fits the transition paradigm. There have been cracks in the system over the thirty-year reform period and it is not difficult to discern between hardliners and softliners in the political discourse as it has unfolded among intellectuals, the state media and occasionally even among the top leaders. Importantly, direct elections for village heads have been instituted in the countryside. Also, there has been a process where the economy and social and cultural norms increasingly have been modernized/Westernized and traditional norms and values have been on the defensive.

Undoubtedly China cannot be categorized as a totalitarian or dictatorial system. However, the reform process has not been linear, rather it has formed a zigzag pattern of two steps forward and one step back. The Chinese political regime should not be treated as an incomplete or transitional form of democracy. It is a hybrid regime, and as comparative political studies show, such a regime can stay hybrid for a long time and prove rather immune to political change (Wheatley and Zurcher 2008). Clearly the Party still dominates the state and its main assets and even controls the commanding heights of the economy through the nomenklatura system. In fact, the country seems to have entered a gray zone of 'dominant-power politics' where it is neither clearly dictatorial nor clearly heading towards democracy (Carothers 2002). So instead of regime breakdown, we see regime resilience-authoritarian resilience to use a concept borrowed from Andrew Nathan (2003).

It is a regime overwhelmingly focused on stability. The core elite has succeeded in turning stability and harmony into the dominant ideological discourse and in the process it has acquired new legitimacy. The current global financial crisis threatens the economic foundation of this stability and may create a new discourse of instability and danger. How the Party-state will cope with such challenges remains to be seen. 
Kjeld Erik Brødsgaard is Director of Asia Research Centre at Copenhagen Business School and Professor of China Studies. (keb.int@cbs.dk)

\section{NOTES}

1 In a recent book, Huang Yasheng (2008) argues that in the economic realm, the 1980s were also characterized by a more dynamic and entrepreneurial reform process than during the 1990s. During the 1990s a recentralization of the economic system and its fiscal instruments took place, creating an environment less conducive to reform. For an opposite view, describing a process of a continued unfolding of reform during the 1990s, see Naughton (2007).

\section{REFERENCES}

Author's Notes 2005. Notes from the China Executive Leadership Programme (CELP). Copenhagen.

Bo, Zhiyue 2004. 'The Institutionalization of Elite Management in China'. In B. Naughton and D. Yang (eds) Holding China Together. Cambridge: Cambridge University Press 2004: 70-100.

Brødsgaard, Kjeld Erik 1981. 'The Democracy Movement in China, 1978-1979: Opposition Movements, Wall Poster Campaigns, and Underground Journals'. Asian Survey 21 (7): 747-75.

- 1987. 'Economic and Political Reform in Post-Mao-China'. Copenhagen Papers in East and Southeast Asian Studies 1: 31-56.

- 2002. 'Institutional Reform and the Bianzhi System in China'. The China Quarterly 170 (June): 361-86.

- 2004. 'Management of Party Cadres in China'. In K. E. Brødsgaard and Y. Zheng (eds) Bringing the Party Back In: How China is Governed. Singapore: Marshall Cavendish 2004: 57-95.

- 2009. Hainan - State, Society, and Business in a Chinese Province. London: Routledge.

- and Y. Zheng (eds) 2004. Bringing the Party Back In: How China is Governed. Singapore: Marshall Cavendish.

Burns, John P. 2004. 'Governance and Civil Service Reform'. In J. Howell (ed.) Governance in China. Lanham, Maryland: Rowman \& Littlefield Publishers 2004: 37-57.

Carothers, Thomas 2002. 'The End of the Transition Paradigm'. Journal of Democracy 13 (1): 5-21.

Central Government Research Team 2008. 'Wo guo jiguan shiye danwei zhigong shouru fenpeizhi yanjiu' [Research on the Income Distribution Mechanism of Employers in Public Service Units in Our Country]. Beijing.

China Directory 2004. Kawasaki: Radiopress, Inc.

'Guowuyuan jigou gaige qingkuang yi lanbiao' [Chart of the Result of the State Council Institutional Reform]. Retrieved on 27 April 2008 from http://finance.sina.com. cn/china/hgij/20080311/16114607809.shtml.

'Guojia guowuyuan zanxin tiaoli' [Provisional Regulations on State Civil Servants]. 1993. Renshibu zhengce faguisi bian. Renshi gongzuo wenjian xuanbian [Selection of Documents Concerning Personnel Work]. Beijing: Zhongguo renshi chubanshe 1994: 5-18. 
Holbig, Heike 2003. 'Chinas neue Regierung Zur Sicherung politischer Legitimitat nach dem X. National Volkskongress'. China aktuell (March): 313-24.

$\mathrm{Hu}$ Jintao 2007. 'Gaoju Zhongguo tese shehuizhuyi weida qizhi, wei duoqu quanmian jianshe xiaokang shehui xin shengli er fendou - zai Zhongguo gongchandang di $17 \mathrm{ci}$ quanguo daibiao dahuishang de baogao' [Hold High the Great Banner of Socialism with Chinese Characteristics, Fight to Achieve New Victories in Comprehensively Building a Comparatively Well-off Society - Report to the $17^{\text {th }}$ National Congress of the CCP]. Renmin ribao (People's Daily), 25 October 2007.

Hua Jianmin 2008. 'Guanyu guowuyuan jigou gaige fangan de shuoming [Concerning the Explanation of the Draft of the State Council Administrative Reform]. Renmin ribao (People's Daily), 12 March 2008.

Huang, Jing 2008. 'Institutionalization of Political Succession in China: Progress and Implications'. In L. Cheng (ed.) China's Changing Political Landscape. Washington, D.C.: Brookings Institution Press 2008: 80-97.

Huang, Yasheng 2008. Capitalism with Chinese Characteristics: Entrepreneurship and the State. Cambridge: Cambridge University Press.

Liu, Jen-Kai 2003. 'China Monthly Data 2003'. China aktuell (March): 345-47.

- 2008. 'Eine neue Runde der Strukturreform des Staatsrats'. China aktuell - Journal of Current Chinese Affairs 2: 140-56.

Miller, Alice L. 2008. 'Institutionalization and the Changing Dynamics of Chinese Leadership Politics'. In L. Cheng (ed.) China's Changing Political Landscape. Washington, D.C.: Brookings Institution Press 2008: 61-79.

Nathan, Andrew 2003. 'Authoritarian Resilience'. Journal of Democracy 14 (1): 6-17.

Naughton, Barry 2007. The Chinese Economy: Transitions and Growth. Cambridge: MIT Press.

Renmin ribao (People's Daily) 2008a. 'Jiu Shenhua xingzheng guanli tizhi he jigou gaige zhongyang bianban fuzeren hui Renmin ribao xinhuashe jizhe wen' [Jiu Shenhua Responsible Person from the Central Office for Administrative Management Reform and Institutional Reform Answers Question from Journalist from People's Daily and Xinhua News]. 12 March 2008.

Renmin ribao (People's Daily) 2008b. 'Zhonggong zhongyang zhengzhiju zhaokai huyi jueding zhaokai ueding zhaokai 17 jie 2 zhong quanhui' [The Politbureau of the Central Committee of the Chinese Communist Party Calls for a Meeting and calls for the Convening of the $2^{\text {nd }}$ Plenary Session of the $17^{\text {th }}$ Central Committee of the CCP]. 23 February 2009.

Renmin ribao (People's Daily) 2008c. 'Xin yilun guowuyuan jigou gaige qidong' [The Launch of a New Round of State Council Institutional Reform]. 12 March 2009.

Shambaugh, David 2008. China's Communist Party: Atrophy and Adaptation. Berkeley: University of California Press.

Voita, Thibaud 2008. 'Les reformes de la NDRC, ou les mues de la planification central'. China Analysis 18 (March-April): 7-8.

Wheatley, Jonathan and Christopher Zurcher 2008. 'On the Origin and Consolidation of Hybrid Regimes: The State of Democracy in the Caucasus'. Taiwan Journal of Democracy 4 (1): 1-32.

Xinhua she (Xinhua News) 2008. 'Guanyu shenhua xingzheng guanli tizhi gaige de yijian' [Opinions Concerning Deepening the Reform of the Administrative Management System]. Retrieved on 4 March 2009 from http:/ / news.xinhuanet.com/newscenter/2008-03/04/content_7717129.htm.

Zhao Ziyang 1987. 'Yanzhe you Zhongguo tese de shehuizhuyi daolu de qianjin' [Advance Along the Road of Socialism with Chinese Characteristics]. Renmin ribao (People's Daily), 4 November 1987. 
Zhonggong zhongyang zuzhibu, Zhonggong dangshi yanjiushi, and Zhongyang dang'an guan 2000. Zhongguo gongchandang zuzhishi ziliao, 1921-1997, fujian 1 [Material on the Organizational History of China's Communist Party, 1921-1997, Appendix, Volume 1]. Beijing: Zhonggong dangshi chubanshe.

'Zhonghua Renmin Gongheguo gongwuyuan fa' [Civil Servant Law of the People's Republic of China]. Retrieved on 27 April 2005 from htpp://www.chinacourt.org. 